University for Business and Technology in Kosovo

UBT Knowledge Center

UBT International Conference

2013 UBT International Conference

Nov 2nd, 9:10 AM - 9:20 AM

\title{
Employment challenges for persons with disabilities (PWD) A case study of Macedonia
}

\author{
Nehat Ramadani \\ University for Business and Technology, nehat.ramadani@ubt-uni.net \\ Violeta Madzova \\ University Goce Delchev, violeta.madzova@ugd.edu.mk
}

Follow this and additional works at: https://knowledgecenter.ubt-uni.net/conference

Part of the Business Commons

\section{Recommended Citation}

Ramadani, Nehat and Madzova, Violeta, "Employment challenges for persons with disabilities (PWD) A case study of Macedonia" (2013). UBT International Conference. 36.

https://knowledgecenter.ubt-uni.net/conference/2013/all-events/36

This Event is brought to you for free and open access by the Publication and Journals at UBT Knowledge Center. It has been accepted for inclusion in UBT International Conference by an authorized administrator of UBT Knowledge Center. For more information, please contact knowledge.center@ubt-uni.net. 


\title{
Employment challenges for persons with disabilities (PWD) A case study of Macedonia
}

\author{
Nehat Ramadani Violeta Madzova \\ Faculty of Management, Business and Economics \\ University for Business and Technology, Prishtine, Kosova \\ nehat.ramadani@ubt-uni.net \\ Faculty of Economics. \\ University Goce Delchev, Stip, Macedonia \\ violeta.madzova.@ugd.edu.mk.
}

\begin{abstract}
This paper raises the issue of employability of Persons with Disabilities in Macedonia. Theoretically reviews the Medical and Social models of Persons with Disabilities (PWD), as well as analyses the international disability rights instruments - UN Convention on the Rights of Persons with Disabilities - and the European Union legislation - Directive on Equal Treatment in Employment and Occupation. The paper thoroughly describes the legislative and strategic framework of Macedonia attempting employment of PWD. It concludes that Macedonia is significantly lagging behind in reforming its social service sector, particularly its system for employment protection of PWD. Public support for employment of persons with disabilities is based on medical diagnosis and partial social actions have been taken to fully integrate these individuals into the society. Public measures are primarily focused on providing small financial support, which goes with remarkable lack of statistical data and reporting on the results. The paper calls for transforming public measures in favor of employability of PWD.
\end{abstract}

Keywor ds: employment, persons with disabilities (PWD), barriers, equality;

\section{Introduction}

Paid work is an important part of our lives. It provides an opportunity to earn an income and also to have social and political status. Work is where many social relationships are formed and social status established. Without the opportunity of working, integration into society can be limited. In add ition, poverty, stemming from unemployment or poor wages, may restrict social and leisure pursuits . Employment helps individuals to define a place in the community. Being employed is essential aspect of culture and identity. Persons with disabilities have very poor employment outcomes compared to the non-disabled part of the labor force. They are more likely to be unemployed for longer periods and face higher risks of losing theirjobs than non-disabled people. At present in European Union, 78\% of persons with disabilities are totally excluded from the workforce. Most of them are obliged to depend on welfare grants to survive and as a result, their income is considerably lower than that of non-disabled people'. This is despite the extensive human rights legislation on international level, which does not allow for discrimination on the grounds of disability if the country is to be considered democratic. An indicator which marks high levels of disability awareness and inclusive policies of a country include, inter alia is the prevalence of labor market employment over special enterprises, quota and other forms of subsidized work for the disabled. It would also determine the status of persons with dis abilities in society as equal with the other citizens. In order for this to happen series of polices need to be developed and implemented, which means adequate legislation, institutional framework and budgets, that will ensure proper adaptations in the environment, access to education and training in mainstream schools and settings, availability of personal assistance and peer counseling, support on the job and effective prohibition of discrimination on the part of employers. Countries have their own specifics when dealing with employment of special target groups of citizens such as PWD. Macedonia, being still a country in development, is lagging behind in reforming its system for employment protection of PWD. It should establish a special system for needs assessment in employment of PWD, which should determine the resources to be given for this purpose. 


\section{Medical and Social model for disabled people}

The literature defines the disability as "any restriction or lack (resulting from an impairment) of an ability to perform an activity in the manner or within the range considered normal for a human being'. A disability may or may not constitute a handicap, which is defined as "disadvantage for a given individual, resulting from an impairment or disability that limits or prevents a role that is normal (depending on age, sex and social or cultural factors) for that individual" The literature shows that the biggest barrier to gaining and advancing in employment the disabled people is the negative attitudes often displayed by employers and co-workers towards disabled people. There are several types and models describing disabled. This paper reviews two models, the so-called models of Medical and Social for PWD.

\subsection{The Medical model of disability}

The medical model of disability is built around the concept of sickness, diagnos is and incapacity. Under the medical model, PWD are defined by their illness or medical condition. They are disempowered: medical diagnoses are used to regulate and control access to social benefits, housing, education, leisure and employment. The medical model promotes the view of a disabled person as dependent and needing to be cured or cared for, and it justifies the way in which persons with disabilities have been systematically excluded from society. The disabled pers on is the problem, not society. Control resides firmly with professionals; choices for the individual are limited to the options provided and approved by the 'helping' expert. The medical model is sometimes known as the 'individual model' because it promotes the notion that it is the individualdisabled person who must adapt to the way in which society is constructed and organized; there is no suggestion that society needs to change. Thus persons with disabilities are made entirely dependent on medical doctors, therapists, social workers and other professionals, as well as on care-givers.

Setting up institutions, special schools and enterprises, day-care centers and other special facilities displays an approach, which is fully consistent with the medical model and calls for 'looking after' or 'taking care' of the people with disabilities. The control lies with the experts and administrators; disabled person has to obey others' decisions. No effort is made to have the environment accessible and friendly because it is not meant to be for persons with disabilities. Disability movement though argues that neither is provided at high quality level, and special education schools fail to develop skills and competences that will make persons with disabilities competitive on the labor market, which makes special enterprises, quota system and subsidized jobs inevitable.

\subsection{The Social model of disability}

The social model has been developed by persons with disabilities in response to the medical modeland the impact it has had on their lives. Under the social model, disability is caused by the society in which we live and is not the 'fault' of an individual disabled person, or an inevitable consequence of their limitations. Disability is the product of the physical, organizational and attitudinal barriers present within society, which lead to discrimination. The removal of discrimination requires a change of approach and thinking in the way in which society is organized.

The social model takes account of persons with disabilities as part of our economic, environmental and cultural society. The barriers that prevent any individual playing a part in society are the problem, not the individual. Barriers still exist in education, information and communication systems, working environments, health and social support services, transport, housing, public buildings and facilities. The devaluing of persons with disabilities through negative images in the media - films, television and newspapers - also acts as a barrier. The social model has been developed with the aim of removing barriers so that persons with disabilities have the same opportunity as everyone else to determine their own life styles. It has fundamentally changed the way in which disability is regarded and triggered adoption of national disability anti-discrimination laws in a number of countries around the world. Thus, the disability is an 'evolving concept' and it 'results from the interaction between persons with impairments and attitudinal and environmental barriers that hinders their full and effective participation in society on an equal basis with others'. "The social model of disability should not be considered as a monolithic entity, but rather as a cluster of approaches to the understanding of the notion of disablement". In the past two decades, and even more so in recent years, there has been an important 
paradigm shift affecting the development of new legislation and policies concerning persons with disabilities (PWDs), from segregation to integration, from institutionalization to mainstreaming, from the medical model of dis ability being viewed as a condition to be treated, to the social model of dis ability focusing on the removal of disabling barriers in the environment that hinder full participation in society.

\section{Dis ability Rights Instruments}

In many countries new disability legislation has been adopted which makes discrimination on the grounds of disability illegal along with requirements for equal treatment through removal of barriers in the environment, including the attitudes, and compensation of the impairment related deficits through technical aids and personal assistance, including peer support and empowerment of the disabled individuals.

Among different instruments across the globe aiming proper treatment of PWD, the paper is focused on the most relevant instruments such as the UN Convention on the Rights of Persons with Disabilities (UN CRPD) and the European Directive on Equal Treatment in Employment and Occupation.

\section{UN Convention on the Rights of Persons with Disabilities (UN CRPD)}

UN CRPD is the first comprehensive human rights treaty of the $21^{\text {st }}$ century and is the first human rights convention to be opened for signature by regional integration organizations. The European Union signed the Convention on the 30 ${ }^{\text {th }}$ March 2007 and ratified it on the $23^{\text {rd }}$ December 2010. The Convention entered into force on $3^{\text {rd }}$ May 2008. It does not provide persons with disabilities new rights; it re-confirms the human rights of all people being valid for the disabled as well. There are eight guiding principles that underlie the Convention and each one of its specific articles:

- Respect for inherent dignity, individual autonomy including the freedom to make one's own choices, and independence of persons

- Non-discrimination

- Full and effective participation and inclusion in society

- Respect for difference and acceptance of persons with disabilities as part of human diversity and humanity

- Equality of opportunity

- Accessibility

- Equality between men and women

- Respect for the evolving capacities of children with disabilities and respect for the right of children with disabilities to preserve their identities

Article 27 of the Convention is explicitly dedicated to work and employment. It requires 'State Parties to recognize the right of persons with disabilities to work, on an equal basis with others; this includes the right to the opportunity to gain a living by work freely chosen or accepted in a labor market and work environment that is open, inclusive and accessible to persons with disabilities. States Parties shall safeguard and promote the realization of the right to work, including for those who acquire disability during the course of employment, by taking appropriate steps'.

\section{European Directive on Equal Treatment in Employment and Occupation}

The European Directive on Equal Treatment in Employment and Occupation was adopted in November 2000 - eight years before the UN CRPD. The Directive prohibits any discrimination, be it direct or indirect, in the field of employment, vocational training, pay and working conditions and membership in organizations of workers or employers on several grounds, including disability.

It is binding only for the EU Member States. The European Commission has the right to take any Member State that fails to adopt such laws or transpose them incorrectly to the European Court of Justice. The Court is also responsible for a uniform interpretation of the Directive.

European Union Member States were required to adopt national laws to ensure compliance with the Directive by December 2006. Unfortunately, the directive is still far from having been implemented at 
level-playing field in all countries. This legislation being quite a useful and strong instrument, the priority is still at national level to make sure that it is implemented and used by persons with disabilities who have been discriminated against. Among the substantive provisions of the Directive, an article on reasonable accommodation is of crucial importance to persons with disabilities. Reasonable accommodation means that the employer must take measures to adapt the working place to a disabled employee, such as removing physical barriers by installing ramps, facilitating access of visually impaired employees to information technologies, or altering working times to accommodate the needs of disabled workers. Failure to provide reasonable accommodation constitutes discrimination for the purpose of the Directive. The Directive applies to all natural and legal persons in the European Union, regardless of whether they are nationals of Member States, and to both public and private employers (whatever the size of the company or the number of employees is). Anyhow, the Employment Directive bares limitations such as: the not strong enough language of the Directive, and its inadequate transposition on the national level. The Joint Employment report of 2011 has underlined that more targeted efforts are needed to support specific groups such as the disabled. The first data published on the situation of persons with disabilities in the labor market (European Labor Force Survey 2002 ad hoc module) shows a very low rate of participation in employment: $78 \%$ of the people with 'severe' disabilities of working age are outside the labor force as compared to $27 \%$ of people without disabilities. Also the unemployment rate is twice as high for disabled job seekers. People with disabilities are largely excluded from the labor market because they are often seen as targets of socio-political measures rather than as potential assets on the labor market. Mainly, disabled people are disadvantaged in the type of participation in the labour force by underemployment - 'poorly paid, low-skilled, low-status jobs which are both unrewarding and undemanding.

\section{Employment of pers ons with disabilities - the case of Macedonia}

In Macedonia, persons with disabilities are still largely seen as objects of charity rather than citizens with the same human rights as other individuals. It is still very rare to find a disabled person in a decision-making position in Macedonia. Persons with disabilities have inadequate educational opportunities. Macedonia has ratified the UN Convention on the Rights of Persons with Disabilities in 2011. This was a major step in the country's commitment "to promote, protect and ensure the full and equal enjoyment of all human rights and fundamental freedoms by all persons with disabilities and to promote respect for their inherent dignity", but still the progress is not visible. Several reports by national and international stakeholders show that most of the PWD are still unable to exercise their right to education. According to these reports it is estimated that only $15 \%$ of children with disabilities are in education, mainly in specialized institutions. The lack of psychologists and education specialists employed in schools, and the existing discrimination against children with disabilities, prevent their inclusion in the education system. In Macedonia, several initiatives for integrated and/or inclusive education have been undertaken, but without a coherent strategy from the Ministry of Education. PWD in Macedonia can only find jobs in segregated, protected workplaces that do not contribute to their social integration. To date, little effort has been made to identify and develop the real capacities of PWD to work in the open market, rather than in sheltered companies. The last European Commission report on the progress made by the Republic of Macedonia towards EU membership, states that little progress has been made in achieving an efficient and inclusive labor market, poverty remains high and inclusion of people with disabilities and other socially excluded groups remains weak.

\subsection{Legislation and strategies}

Employment of persons with disabilities in Macedonia is regulated by a special legislation - Law on Employment of People with Disabilities - which sets the conditions for the employment of persons with disabilities. The Law on Employment of Persons with Disabilities was combined with setting up of a Special Fund to finance the activities that aim at improving the conditions for employment and work of disabled people. It gives opportunities for adaptation of the work place, procurement of equipment, vocational training of persons with disabilities for specific assignments according to the employer's needs and the needs of the disabled people, as well as the benefits that the employer is receiving for taxes relief. This Law regulates the specific conditions for employment and working of persons with disabilities, when they run their own business, when they are employed in companies owned by other 
owners and at the same time it regulates the conditions for establishing a sheltered company for employment of disabled people. The National Strategy on Equality and Non-discrimination 20122015,was enacted in 2011 with special emphas is on the discrimination field, which is faced by the most vulnerable groups in the country. This document included actions for employment and job opportunities for people with mental and physical impairments on an equal basis with others. The activities designed to achieve the strategic goal are focused on strengthening the capacity of all stakeholders to implement the appropriate adjustments in the workplace for people with mental and physical disabilities. National Strategy on Alleviation of Poverty and Social Exclusion 2010-2020 the main strategic objective is to reduce poverty and social exclusion in the country, through better use of available human and material resources, improvement of living, working and social conditions for all citizens and institutional coactivity in the function of accelerated development, higher standards and better quality of life. National Strategy on Equalization of the Rights of the People with Disabilities (revised) 2010- 2018 is another strategic document which aims to improve the position of Persons with disabilities to a position of equal citizens who enjoy all rights and responsibilities. The strategy was firstly adopted in 2000 and was based on European and national legislation and on the Standard Rules for Equalization of the Opportunities for PWD.

Anyhow, the labor legislation must not contain any provision that discriminates against PWD concerning their employment. At the same time, the Government should institute support programs on inclusion of persons with disabilities in the labor market.

\section{Employment situation of people with disabilities in Macedonia}

In general, large organizations, are more likely than smaller organizations to proactively recruit people with disabilities, to have formal return to work or disability management programs, and to accommodate the needs of employees with disabilities. Small employers typically have no trained staff to manage work accommodations, limited opportunities for shifting workers with disabilities into other jobs in the company, and often lack generous health or disability benefits. According to the data of the State Statistical Office of 2013, the labour force in the Republic of Macedonia numbered 952327 persons, of which 678467 were employed, while 273860 were unemployed persons. The activity rate in this period was 57.1 , the employment rate was 40.7 , while the unemployment rate was 28.8 . $36 \%$ of the social care beneficiaries in the country are persons with disabilities (20,402 persons). Civil society organizations and associations of persons with disabilities count 90,000 members, but the data are not officially proved.

Based to the official data from the Employment Service Agency of the Republic of Macedonia, the total number of registered unemployed disabled people is like following:

Table 1. Number of unemployed PWD in Macedonia

\begin{tabular}{lll}
\hline Year & Unemployed PWD & Women \\
\hline 2009 & 2089 & 715 \\
2010 & 2326 & 809 \\
2011 & 2165 & 777 \\
2012 & 2034 & 753 \\
\hline Source: Employment Service Agency of R. Macedonia
\end{tabular}

The segregated data by age of unemployed people with disabilities in the Republic of Macedonia shows increase to the category of people aged between 25 and 54 years.

Table 2. Unemployed PWD by age 


\begin{tabular}{llllllllllll}
\hline Year & Total & $\begin{array}{l}\mathbf{1 5 - 1 9} \\
\text { years }\end{array}$ & $\begin{array}{l}\mathbf{2 0 - 2 4} \\
\text { years }\end{array}$ & $\begin{array}{l}\mathbf{2 5 - 2 9} \\
\text { years }\end{array}$ & $\begin{array}{l}\mathbf{3 0 - 3 4} \\
\text { years }\end{array}$ & $\begin{array}{l}\mathbf{3 5 - 3 9} \\
\text { years }\end{array}$ & $\begin{array}{l}\mathbf{4 0 - 4 4} \\
\text { years }\end{array}$ & $\begin{array}{l}\mathbf{4 5 - 4 9} \\
\text { years }\end{array}$ & $\begin{array}{l}\mathbf{5 0 - 5 4} \\
\text { years }\end{array}$ & $\begin{array}{l}\mathbf{5 5 - 5 9} \\
\text { years }\end{array}$ & $\begin{array}{l}\mathbf{6 0} \text { Y } \\
\text { and } \\
\text { more }\end{array}$ \\
\hline 2009 & 2089 & 42 & 195 & 268 & 272 & 287 & 221 & 239 & 232 & 199 & 116 \\
2010 & 2326 & 37 & 206 & 318 & 295 & 341 & 256 & 253 & 263 & 216 & 141 \\
2011 & 2165 & 33 & 192 & 287 & 271 & 298 & 252 & 220 & 280 & 208 & 124 \\
2012 & 2034 & 21 & 164 & 265 & 261 & 276 & 246 & 212 & 250 & 214 & 125 \\
\hline
\end{tabular}

Source: Employment Service Agency of R. Macedonia

According to the data of the Employment Service Agency, there are around 393 registered sheltered companies in the country, which employ around 3442 persons with disabilities.

\subsection{Applied measures for employment of people with disabilities in Macedonia}

Persons with disabilities who are registered as unemployed in the Employment Agency are being also included in active labor market measures carried out by the Government of Republic of Macedonia and the Employment Agency, in accordance with the Operation Plan for active employment programs and measures for 2012 and 2013 .

According to the Operational Plan for active employment programs and measures for 2012 and 2013, the Employment Agency is subsidizing the employment of disabled people. Subsidies are granted in accordance with the Law on Employment for Persons with Disabilities and the Rules on the criteria and the manner of allocation of grants from the Special Fund for improvement of the conditions for employment and work of the disabled persons. The total amount forecasted for 2012 for these measures is $€ 3$. 040.650 (187.000.000 MKD), covering 200 registered unemployed persons with disabilities and 300 registered unemployed persons with disabilities with a budget of $€ 3.121 .951$ (192,000,000 MKD).

The same source shows that the Special Fund within the Ministry of Labor and Social Policy, which supports employment of people with disabilities during the past three years, has supported around 1900 people. The Special Fund grants are awarded for employment of persons with disabilities under openended contracts, for adaptations of the workplace, procurement of equipment and vocational training of disabled persons for the purposes of employment.

Anyhow, in general based also on the data above and its approach, Macedonia is significantly lagging behind in reforming its social service sector, particularly its system for protection of PWD. The current system dates back to the Socialist Federative Republic of Yugoslavia when a medical model of extensive and strongly institutionalized services had been provided. The process of transition which started in 1991, after the country's independence, reduced the social sector's financial resources and consequently, the level of care and benefits enjoyed by persons with disabilities. Only partial social actions have been taken to fully integrate these individuals into the society, and they primarily focused on providing small financial support. Given the UN CRPD provisions, which after the ratification by the Macedonian State in December 2011, it would be necessary to consider the entire disability related legal framework and make it in compliance with the Convention. Part of it will certainly cover employment policies. This will require a comprehensive review of the general employment legislation - not for persons with disabilities alone - with UN CRPD as a framework of reference. Given that current policy documents, developed quite recently in Macedonia, have similar goals, it should not be impossible to modify them and bring them in line with modern practices of effective employment of persons with disabilities in the mainstream labor market.

\section{Conclusions}

Despite the UN CRPD and its massive ratification by many countries, including the European Union, despite the European legis lation on non-discrimination and equal treatment in employment, neither EU Member States as a whole nor any particular country including Macedonia, has achieved remarkable results in employment of persons with disabilities. Nevertheless, inclusive employment measures and 
mainstreaming of the employment promotion activities is proclaimed on political level across EU. Macedonia does not represent any exception in this regard. It is quite obvious that the Macedonian state allocates vast financial resources in employment of persons with disabilities, which goes with remarkable lack of statistical data and reporting on the results. Available numbers show very few people with disabilities in employment, which calls for comprehensive evaluation of the existing policy measures and programs. One of the reasons could be seen in the education system - few persons with disabilities are well educated and skillful to compete on the open labor market - though lack of accessibility in the mainstream environment and personal supports, cumulatively, could also contribute to low effectiveness of the policy measures. Public support for employment of persons with disabilities in Macedonia follows the general disability assessment procedures and is based on medical diagnosis. This approach limits the opportunities to respond to the needs of persons with disabilities, which are strictly related to employment - education, professional skills, social skills, transport, technical aids, personal assistance on the job, etc. It is necess ary to establish a special systemfor needs assessment in employment, which should determine the resources to be given to each individual in order to perform on a particular position when hired. This implies transforming public measures in favor of employability of PWD in Macedonia. Application of such individualized approach is not only in line with the principles of the international Conventions, but ensures better effectiveness and efficiency of the public expenditures.

\section{References}

1. Americans with Disabilities Act of 1990 ; Disability Discrimination Act passed in 1995 in UK ; Law on Integration of Disabled People, passed in 2004 by the Bulgarian Parliament;

2. Anna Jameson, 2005, Disability and employment- Review of Literature and Research, EEO Trust, New Zeland. P.6;

3. European Commission, 2011, Annual Growth Survey Annex 3; Draft Joint Employment Report ; DRAFT JOINT EMPLOYMENT REPORT; Brussels, p.10;

4. European Commission. The FYROM 2012 Progress Report. Brussels 2012. p.54;

5. European Disability Forum [2010], Ten years on: practical impact of the Employment Directive on persons with disabilities in employment EDF Analysis of Council Directive 2000/78/EC;

6. Jongbloed, L. \& Crichton, A. (1990). Difficulties in shifting from individualistic to socio-political policy regarding disability in Canada. Disability, Handicap, \& Society, 5(1), 25-36;

7. Karen Johns, 1995, Employment and Training Policies for People with Disabilities: A Literature Review, Wellington, New Zeland, p.6

8. Law on Employment of People with Disabilities, 44/2000, 16/2004, 62/2005, 113/2005, 29/2007, 88/2008, 161/2008;

9. Mark L. Lengnick-Hall, Philip M. Gaunt, Adrienne A. R. Brooks , 2002, Why employers don't hire people with disabilities: A survey of the literature, College of Business, University of Texas at San Antonio, p.5;

10. Ministry of Labor and Social Policy R.Macedonia, Operation Plan for active employment programs and measures for 2012 and 2013;

11. Ministry of Labor and Social Policy R.Macedonia, Operation Plan for active employment programs and measures for 2012 and 2013

12. National Strategy on Alleviation of Poverty and Social Exclusion in the Republic of Macedonia 2010-2020;

13. National Strategy on Equalization of the Rights of the People with Disabilities (Revised) 20102018;

14. Patricia Thornton and Neil Lunt, (?), Employment for Disabled People social obligation or individual responsibility?, p.6;

15. Public Service Commission of Canada, 2011, Recruitment of persons with disabilities -a literature review, Cat. No. SC3-156/2011E-PDF ISBN 978-1-100-18669-6, p.7;

16. Raymond Lyng, 2007, The development and critique of the social model of disability, UCL, p.2 ;

17. Reference from the Conference on disabled employment, held on December 6, 2012 Skopje;

18. State Statistical Office of Macedonia, Active Population in the Republic of Macedonia Results from the Labour Force Survey, 2013; 
19. The European Trade Union Confederation (ETUC) and the European Disability Forum, 2007, ETUC-EDF Joint Declaration, Lisbon, p.1.;

20. The National Strategy on Equality and Non-discrimination in the Republic of Macedonia 20122015;

21. UN Convention on the Rights of Persons with Disabilities, 2006 , Guiding Principles of the Convention, UN New York;

22. UN Convention on the Rights of Persons with Disabilities, 2006 , Guiding Principles of the Convention, UN New York; 